\title{
Quaternary Phosphonium Iodides as Organic Iodide Sources for Dye-Sensitized Solar Cells
}

\author{
Yoshihito Kunugi $^{1 *}$, Naoki Hamada ${ }^{1}$, Katsuhiko Tsunashima ${ }^{2}$ and Masashi Sugiya ${ }^{2}$ \\ ${ }^{1}$ Department of Applied Chemistry, Faculty of Engineering, Tokai University, \\ 1117 Kitakaname, Hiratsuka, 259-1292, Japan \\ *ykunugi@keyaki.cc.u-tokai.ac.jp \\ ${ }^{2}$ Organic Chemicals $R \& D$ Department, Nippon Chemical Industrial Co., Ltd., \\ 9-11-1, Kameido, Koto-Ku, Tokyo, 136-8515, Japan
}

\begin{abstract}
Keywords : Dye-sensitized solar cell, Quaternary phosphonium iodide, Organic-inorganic hybrid electrolyte, Highly efficient DSSC
\end{abstract}

\section{Introduction}

Dye-sensitized solar cells (DSSCs) have attracted much attention as flexible, colorful and low-cost solar cells [1-5]. The design of the DSSC is a relatively simple one, consisting of a dye-adsorbed nanoporous titanium dioxide $\left(\mathrm{TiO}_{2}\right)$ electrode, an electrolyte containing an iodide/triiodide redox couple and a platinum-coated conducting glass electrode. In order to improve the DSSC performance, variations in cell performance with different dyes, redox couples, electrolytes and electrodes have been widely studied [6-10]. The electrolyte is particularly influential component of the DSSC. For example, it is well known that lithium cations increase the short circuit current $\left(J_{\mathrm{sc}}\right)$ while decreasing the open circuit voltage $\left(V_{\mathrm{oc}}\right)$ [11]. Novel organic iodine sources are being widely investigated as effective DSSC components [12-15]

$$
\mathrm{R}^{1}-\mathrm{P}_{\mathrm{R}^{1}}^{\mathrm{P}^{+}-\mathrm{R}^{2}} \mathrm{I}^{-}
$$

$\mathbf{P}_{2221} \mathbf{- I}: \mathrm{R}^{1}=\mathrm{C}_{2} \mathrm{H}_{5}, \mathrm{R}^{2}=\mathrm{CH}_{3}$

$\mathbf{P}_{2222}$-I : $\mathrm{R}^{1}=\mathrm{C}_{2} \mathrm{H}_{5}, \mathrm{R}^{2}=\mathrm{C}_{2} \mathrm{H}_{5}$

$\mathbf{P}_{2225}$-I : $\mathrm{R}^{1}=\mathrm{C}_{2} \mathrm{H}_{5}, \mathrm{R}^{2}=\mathrm{C}_{5} \mathrm{H}_{11}$

$\mathbf{P}_{4441^{-I}}: \mathrm{R}^{1}=\mathrm{C}_{4} \mathrm{H}_{9}, \mathrm{R}^{2}=\mathrm{CH}_{3}$

$\mathbf{P}_{4444}-\mathrm{I}: \mathrm{R}^{1}=\mathrm{C}_{4} \mathrm{H}_{9}, \mathrm{R}^{2}=\mathrm{C}_{4} \mathrm{H}_{9}$

Figure 1. Molecular structures of quaternary phosphonium iodides.
Recently, we synthesized novel quaternary phosphonium ionic liquid and used it as a nonvolatile and highly ionic conductive electrolyte for the DSSC [16-18]. Interestingly, the energy conversion efficiencies for the quaternary phosphonium ionic liquid electrolytes were higher than those for the corresponding quaternary ammonium ionic liquids. In this paper, we investigate a variety of quaternary phosphonium iodides as novel organic iodide sources for DSSCs (Fig. 1).

\section{Experimental}

Quaternary phosphonium iodides were synthesized as described in previous papers $[16,19]$. For example, triethyl(methyl)phosphonium iodide $\left(\mathrm{P}_{2221} \mathrm{I}\right)$ was synthesized by nucleophilic addition of triethylphosphine to iodomethane, and the resulting iodide was purified by recrystallization and then dried under vacuum. Other materials used were reagent grade or better and used as received.

DSSC photoanodes were prepared as follows: $\mathrm{TiO}_{2}$ nano-particles (Solaronix D) were coated over fluorine-doped $\mathrm{SnO}_{2}$-coated glass electrodes (Asahi glass Co. Ltd., $10-11 \Omega \mathrm{cm}^{-2}$ ) and sintered at $450{ }^{\circ} \mathrm{C}$ for $30 \mathrm{~min}$. The photoanodes $\left(\mathrm{TiO}_{2}\right.$ thickness: ca. $15 \mu \mathrm{m}$, area: ca. $0.7 \mathrm{~cm} \times 0.7 \mathrm{~cm}$ ) were dipped into $0.5 \mathrm{mmol} \mathrm{l}^{-1}$ cis-di(thiocyanato)-N,N-bis(2,2'-bipyridyl-4,4'-dic arboxylic acid)ruthenium(II) complex (N3 dye) ethanol solution at $40{ }^{\circ} \mathrm{C}$ for several hours and treated with ethanol and acetonitrile. The N3-immobilized photoanode and platinum- 
deposited electrode were sandwiched together using cell holders, and electrolytes were infiltrated into the resulting cells. The standard (conventional) electrolyte consisting of $0.1 \mathrm{~mol} \mathrm{l}^{-1}$ LiI, $0.05 \mathrm{~mol} \mathrm{l}^{-1} \mathrm{I}_{2}, 0.6 \mathrm{~mol} \mathrm{l}^{-1}$ 1,2-dimethyl3-propylimidazolium iodide and $0.5 \mathrm{~mol}^{-1}$ 4-t-butylpyridine were dissolved in methoxyacetonitrile $[15,16]$. The photoanodes were covered by a shadow mask and the active area of the electrode was $0.283 \mathrm{~cm}^{2}$ (radius $=0.3$ $\mathrm{cm})$.

Photocurrent-voltage characteristics were measured with a Keithley 2400 source meter and an AM 1.5 solar simulator (Peccell PEC-L10N) equipped with a $500 \mathrm{~W}$ xenon lamp. Measurements were performed at room temperature under ambient conditions.

\section{Results and discussion}

In order to compare this with a conventional electrolyte, we set the cation concentration to 0.7 mol $1^{-1}$. The photovoltaic parameters of DSSCs using various quaternary phosphonium iodide based electrolytes under full sunlight illumination (AM 1.5, $100 \mathrm{~mW} \mathrm{~cm}^{-2}$ ) are summarized in Table 1. 4-t-butylpyridine is known to prevent the $\mathrm{TiO}_{2}$ conduction potential from making a positive shift which is caused by adsorption on the $\mathrm{TiO}_{2}$ surface [20]. $\mathrm{P}_{2222}-\mathrm{I}$ was not dissolved with $\mathrm{a}$ concentration of $0.7 \mathrm{~mol} \mathrm{l}^{-1}$ in methoxyacetonitrile, while other quaternary phosphonium iodides were completely dissolved in the electrolyte at room temperature. For the quaternary phosphonium

Table 1. Photovoltaic parameters of DSSCs using various quaternary phosphonium and imidazolium iodides based electrolytes. ${ }^{\text {a) }}$

\begin{tabular}{ccccc}
\hline Iodide & $\begin{array}{c}J_{\mathrm{sc}} \\
/ \mathrm{mA} \mathrm{cm}^{-2}\end{array}$ & $\begin{array}{c}V_{\mathrm{oc}} \\
/ \mathrm{mV}\end{array}$ & $f f$ & $\begin{array}{c}\eta \\
/ \%\end{array}$ \\
\hline $\mathrm{P}_{2221} \mathrm{I}$ & 16.6 & 661 & 0.60 & 6.6 \\
$\mathrm{P}_{2222} \mathrm{I}$ & $-^{*}$ & $-^{*}$ & $-^{*}$ & $-^{*}$ \\
$\mathrm{P}_{2225} \mathrm{I}$ & 15.9 & 665 & 0.57 & 6.0 \\
$\mathrm{P}_{4441} \mathrm{I}$ & 15.0 & 676 & 0.58 & 5.9 \\
$\mathrm{P}_{4444} \mathrm{I}$ & 14.9 & 681 & 0.57 & 5.8 \\
DMPIm-I & 16.6 & 678 & 0.61 & 6.9 \\
EMIm-I & 16.1 & 668 & 0.63 & 6.8 \\
\hline
\end{tabular}

a) electrolyte: $0.7 \mathrm{~mol} \mathrm{l}^{-1}$ quaternary phosphonium or imidazolium iodides, $0.05 \mathrm{~mol} \mathrm{l}^{-1} \mathrm{I}_{2}$ and $0.5 \mathrm{~mol} \mathrm{l}^{-1}$ 4-t-butylpyridine were dissolved in methoxyacetonitrile.

* $\mathrm{P}_{2222}$-I was not completely dissolved in the electrolyte. series, decreasing alkylchain length (cation size) increased the short-circuit current $\left(J_{\mathrm{sc}}\right)$, while the open-circuit voltage $\left(V_{\mathrm{oc}}\right)$ increased slightly with increasing the cation size, whereas fill factors $(f f)$ were almost the same. The best device performance was achieved using $\mathrm{P}_{2221} \mathrm{I}$ as iodide source, whose energy conversion efficiency $(\eta)$ was $6.6 \%$ under full sunlight illumination. This value is comparable with or slightly lower than those of imidazolium based electrolytes.

As described above, lithium cation improves cell performances: therefore, we investigated lithium containing organic-inorganic hybrid cation based electrolytes for DSSCs. The role of the lithium cation is to increase the electron injection yield [21]. Figure 2 shows the photocurrent density-voltage characteristics for DSSC devices based on phosphonium-lithium and imidazolium-lithium hybrid (conventional) electrolytes. Interestingly, the short-circuit current for the $\mathrm{P}_{2221}-\mathrm{I}$ and $\mathrm{P}_{4441}-\mathrm{I}$ based electrolytes is higher than for the DMPIm-I based electrolyte, while the fill factors were slightly lower than those for the DMPIm-I. The photovoltaic parameters of the DSSCs based on various organic-inorganic

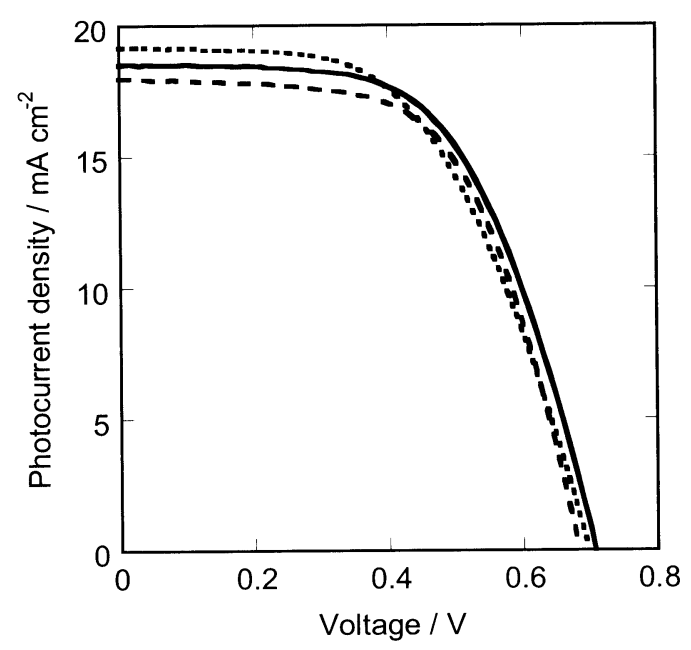

Figure 2. Photocurrent density-voltage characteristics of DSSC devices using $\mathrm{P}_{2221}$-I (solid line), $\mathrm{P}_{4441}-\mathrm{I}$ (dotted line) and DMPIm-I (standard, dashed line) electrolytes under AM 1.5 simulated full sunlight (100

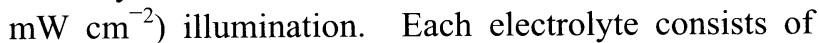
$0.1 \mathrm{~mol} \mathrm{l}^{-1} \mathrm{LiI}, 0.05 \mathrm{~mol} \mathrm{l}^{-1} \mathrm{I}_{2}, 0.6 \mathrm{~mol} \mathrm{l}^{-1}$ organic iodide and $0.5 \mathrm{~mol} \mathrm{l}^{-1}$ 4-t-butylpyridine were dissolved in methoxyacetonitrile. 
Table 2. Photovoltaic parameters of DSSCs based on organic-inorganic hybrid electrolyte containing quaternary phosphonium and imidazolium iodides. ${ }^{\text {a) }}$

\begin{tabular}{ccccc}
$\begin{array}{c}\text { Organic } \\
\text { iodide }\end{array}$ & $\begin{array}{c}J_{\mathrm{sc}} \\
\mathrm{mA} \mathrm{cm}^{-2}\end{array}$ & $\begin{array}{c}V_{\mathrm{oc}} \\
/ \mathrm{mV}\end{array}$ & $f f$ & $\begin{array}{c}\eta \\
/ \%\end{array}$ \\
\hline $\mathrm{P}_{2221}-\mathrm{I}$ & 18.5 & 708 & 0.59 & 7.7 \\
$\mathrm{P}_{2225}-\mathrm{I}$ & 17.5 & 672 & 0.58 & 6.8 \\
$\mathrm{P}_{4441}-\mathrm{I}$ & 19.2 & 698 & 0.55 & 7.4 \\
$\mathrm{P}_{4444}-\mathrm{I}$ & 17.1 & 689 & 0.54 & 6.4 \\
$\mathrm{DMPIm} \mathrm{I}$ & 18.0 & 683 & 0.61 & 7.5 \\
$\mathrm{I}^{\mathrm{b})}$ & 18.0 & 672 & 0.59 & 7.1 \\
$\mathrm{II}^{\mathrm{c})}$ & 18.8 & 699 & 0.59 & 7.8 \\
\hline
\end{tabular}

a) electrolyte: $0.1 \mathrm{~mol} \mathrm{l}^{-1} \mathrm{LiI}, 0.6 \mathrm{~mol} \mathrm{l}^{-1}$ organic iodides, $0.05 \mathrm{~mol} \mathrm{l}^{-1} \mathrm{I}_{2}$ and $0.5 \mathrm{~mol} \mathrm{l}^{-1}$

4-t-butylpyridine were dissolved in methoxyacetonitrile. b) organic iodide: $0.3 \mathrm{~mol} \mathrm{l}^{-1}$ $\mathrm{P}_{2221} \mathrm{I}+0.3 \mathrm{~mol} \mathrm{l}^{-1}$ DMPIm-I $\quad$ c) organic iodide: 0.3 $\mathrm{mol} \mathrm{l}^{-1} \mathrm{P}_{4441}-\mathrm{I}+0.3 \mathrm{~mol} \mathrm{l}^{-1}$ DMPIm-I

hybrid electrolytes containing quaternary phosphonium and imidazolium iodides are summarized in Table 2. The energy conversion efficiency for the $\mathrm{P}_{2221}$-I and $\mathrm{P}_{4441}$-I based electrolytes were comparable to or slightly higher than those of the DMPIm-I based standard electrolyte. It is quite significant that the DSSC performance with easily synthesized phosphonium iodide is comparable to that with costly imidazolium iodide. The best device performance was achieved using a mixed organic iodide (II: $\mathrm{P}_{4441}$-I:DMPIm-I = 1:1), whose energy conversion efficiency $(\eta)$ was $7.8 \%$ under full sunlight illumination. At this time, the effect of the phosphonium cation on DSSC performance cannot be understood sufficiently and is under investigation.

\section{Conclusion}

DSSCs using quaternary phosphonium iodides as their organic iodide sources were successfully fabricated. Interestingly, the DSSC performances for the $\mathrm{P}_{2221}-\mathrm{I}$ and $\mathrm{P}_{4441}$-I based electrolytes were comparable to or slightly better than that of the standard electrolyte. Phosphonium-based iodides are promising organic iodide sources for practical DSSC cells.

\section{References}

1. B. O’Regan, M. Grätzel, Nature, 353 (1991)
737.

2. M. Grätzel, Nature, 414 (2001) 338.

3. J. Wu, S. Hao, Z. Lan, J. Lin, M. Huang, Y. Huang, P. Li, S. Yin, T. Sato, J. Am. Chem. Soc., 130 (2008) 11568.

4. L. Han, A Fukui, Y. Chiba, A Islam, R. Komiya, N, Fuke, N. Koide, R. Yamanaka, M. Shimizu, Appl. Phys. Lett., 94 (2009) 013305.

5. T. Miyasaka, Mirai Zairyo, 8(12) (2008) 19.

6. M. Gorlov, L. Kloo, Dalton Trans., (2008) 2655.

7. M. K. Nazeeruddin, F. D. Angelis, S. Fantacci, A. Selloni, G. Viscardi, P. Liska, S. Ito, B. Takeru, M. Grätzel, J. Am. Chem. Soc., 127 (2005) 16835.

8. Y. Chiba, A. Ishraful, Y. Watanabe, R. Komiya, N. Koide, L. Han, Jpn. J. Appl. Phys., 45 (2006) L638.

9. M. Ikegami, K. Miyoshi, T. Miyasaka, K. Teshima, T. C. Wei, C. C. Wan, Y. Y. Wang, Appl. Phys. Lett., 90 (2007) 153122.

10. N. Koumura, Z.-S. Wang, S. Mori, M. Miyashita, E. Suzuki, K. Hara, J. Am. Chem. Soc., 128 (2006) 14256.

11. H. G. Agrell, J. Lindgren, A. Hagfeldt, $J$. Photochem. Photobiol. A, 164 (2004) 23.

12. N. A. Leweenko, M. J. Byrnes, Y.-B. Cheng, S. M. Zakeeruddin, M. Grätzel, L. Spiccia, Chem. Commun., (2008) 3852.

13. J.-G. Chen, V. Suryanarayanan, K.-M. Lee, K.-C. Ho, Sol. Energy. Mater. Sol. Cells, 91 (2007) 1432.

14. X. Liu, Da Qin, Y. Fan, K. Li, D. Li, Q. Meng, Electrochem. Commun., 9 (2007) 1735.

15. T. Kanzaki, S. Nakade, Y. Wada, S. Yanagida, Photochem. Photobiol. Sci., 5 (2006) 389.

16. Y. Kunugi, H. Hayakawa, K. Tsunashima, M. Sugiya, Bull Chem. Soc. Jpn., 80 (2007) 2473.

17. K. Tsunashima, M. Sugiya, Electrochem. Commun., 9 (2007) 2353.

18. K. Tsunashima, M. Sugiya, Electrochemistry, 75 (2007) 734.

19. W. A. Henderson Jr., S. A. Buckler, J. Am. Chem. Soc., 82 (1960) 5794.

20. S. Nakade, T. Kanzaki, W. Kubo, T. Kitamura, Y. Wada, S. Yanagida, J. Phys. Chem. B, 109 (2005) 3480.

21. Y. Liu, A. Hagfeldt, X.-R. Xiao, S.-E. Lindquest, Sol. Energy Mater. Sol. Cells, 55 (1998) 267. 